\title{
Legal Consequences of Acquiring Company of Mining License Holder That Has Not Obtained Government Approval toward Mining License Transfer and Control
}

\author{
Danang Muhammad Zawahirul Fahmi; Sukanda Husin; Rembrandt \\ Faculty of Law, Andalas University, Padang, Indonesia
}

http://dx.doi.org/10.18415/ijmmu.v6i3.908

\begin{abstract}
The objectives of this research are 1) to find out the legal consequences of acquiring company of mining license holder that has not obtained government approval toward mining license transfer and control, 2) to find out the legal liabilities of company that acquires company of mining license holder. This legal research applies the method of normative juridical legal approach. The data analysis technique employs qualitative analysis. The results of this research revealed that the acquirer actually does not have any legal liability to the acquired party unless the acquirer is indeed proven to have committed bad faith during and after the acquisition process which could harm other parties including third parties. Thus, the acquirer can be held directly liable through the court or other ways. Meanwhile, the legal liability of the acquired party is that they must carry out an administrative process to the relevant agencies namely the Ministry of Energy and Mineral Resources, to fulfill the provisions referred to in Article 93 of the Mineral and Coal Law. The party that acquires the company of mining license holder has the same obligation as the acquired party. The acquirer must comply with the provisions in the form of obligations which are required to the mining license holder such as the provisions of Article 95 up to 112 of Mineral and Coal Law.
\end{abstract}

Keywords: Law; Acquisition; Company; Mining Business

\section{Introduction}

Mining is an industry that can provide high economic benefits. Excavation of natural resources, in the form of minerals and coal, may provide a significant contribution to the state's financial resources. Indonesia is one of the countries in the world that has abundant reserves of natural resources. This natural resource is better known as minerals and coal. Minerals and coal contained in the Indonesian legal jurisdiction are non-renewable natural wealth as the gift of God Almighty. It has an important role in fulfilling the lives of many people. Therefore, the management must be controlled by the State ${ }^{1}$ to provide the real added value to the national economy in an effort to achieve prosperity and equitable welfare of

\footnotetext{
${ }^{1}$ Law No. 5 of 1960 concerning Basic Regulations on Agrarian Principles Article 2 paragraph (2) explaining that State control rights authorize to: a. regulate and administer the designation, use, supply and maintenance of the earth, water and space; $b$. determine and regulate legal relations between people and earth, water and space; c. determine and regulate the legal relationships of people and legal actions concerning the earth, water and space.
} 
the people. ${ }^{2}$ Chapter III of Law No. 4 of 2009 concerning Mineral and Coal Mining, Article 4 paragraph (2) states that "Acquisition of minerals and coal by the state as referred to in paragraph (1) shall be carried out by the government and/ or regional government".

Regulations regarding the use of natural resources in the mineral and coal mining sector in Indonesia were first regulated under Law No. 11 of 1967 concerning the Basic Provisions of Mining. In this law, mining of minerals and coal is regulated through mining rights, contracts or agreements. ${ }^{3}$ Largescale mining is regulated by the state and the form of granting rights to the company is carried out through Work Contract and Coal Mining Concession Work Agreement. Meanwhile, small-scale mineral and coal mining is regulated by the regency/ city government and carried out through Mining Authority.

The form of the contract and license has a fundamental difference. In the form of contracts, the government and mining company are two parties that are in a parallel position. Meanwhile, the form of license places the government in a higher position on the company of license holder. This change in paradigm led to differences of opinion, especially between the company of Work Contract holder and the government. First, the Work Contract holder assumes that the agreement is a Law for those who make it, as the characteristics of the agreement in the provisions of Article 1338 of the Civil Code, ${ }^{4}$ which states that all agreements made legally apply as laws for the parties who make them (principle of pacta sunt servanda). As the consequence, either the judge or the third party cannot interfere with the contents of the agreement. ${ }^{5}$

In Indonesia, the source of dispute over mining areas generally starts with the issuance of license by the regional government. Investors' concerns arise because of uncertain legal and political situations. Investors who invest in developing countries such as Indonesia generally demand the country's readiness from aspects of security and legal certainty in investment. ${ }^{6}$ For instance, one of the cases that caused concern for domestic and foreign investors is the case of license in the mining area, one of which was in Penajam Paser Utara Regency, East Borneo Province. In this case, PT Pasir Prima Coal Indonesia (hereinafter abbreviated as PT PPCI) filed a lawsuit to the Administrative Court related to the decision of the Regent of Penajam Paser Utara No. 460/63/Distamben/II/2011 dated February 7, 2011 concerning Revocation of Decree of the Regent of Penajam Paser Utara No. 545/03-Exploitation/Economi/VI/2008 concerning License for Coal Mining Exploitation at PT PPCI. Based on the Regent's decision dated February 7, 2011, one of the bases for revoking the Mining Authorization License was the change of the President Director whose changes had not received approval from the Minister.

Unfortunately, for the above case, before the revocation of PT PPCI's Mining Authority, the government did not consider the legal aspects of the acquisition or transfer of shares in a limited liability company law. Acquisition is an internal legal act of a corporate legal entity. This action does not need to get ministerial approval but it must be reported to the minister and must be included in a special register as required by Article 50 Paragraph (1) of the Limited Liability Company Law. So, this legal event is not the same as the transfer of rights to shares or the transfer of share ownership in the capital market as stipulated in Article 56 Paragraph (5) of Law No. 40 of 2007 concerning Limited Liability Company.

Therefore, the authors are interested in conducting research under the title: legal consequences of acquiring company of mining license holder that has not obtained government approval toward mining license transfer and control.

\footnotetext{
${ }^{2}$ Indonesia, Law of the Republic of Indonesia No. 4 of 2009 concerning Mineral and Coal Mining, in reviewing the letter "a".

${ }^{3}$ Ahmad Redi, 2017, Law on the Settlement of Mineral and Coal Mining Disputes, Grafika Offset, Jakarta, page 26

${ }^{4}$ Article 1338 of Civil Code: "All agreements are made in accordance with the applicable Law as a Law for those who make it. The agreement is irrevocable other than by agreement of both parties or for reasons determined by the Law. Approval must be carried out in good faith. (Civil Code 751, 1066, 1243 etc., 1266 etc., 1335 etc., 1363, 1603, 1611, 1646-3?, 1688, 1813.).”

${ }^{5}$ Ridwan Khairandy, 2015, Freedom of Contracting \& Pacta Sunt Servanda Versus Good Etiquette: Attitudes that Must Be Taken by the Court, FHUIIPress, Yogyakarta, page 38.

${ }^{6}$ Camelia Malik, "Legal Certainty Insurance in Investment Activities in Indonesia", article on the Business Law Journal, (JulySeptember 2007), page 16
} 


\section{Research Method}

Generally, research aims to find, develop or test the truth of a knowledge. As a scientific work, the thesis must be carried out through appropriate research methodology so that the writer will be assisted to find, formulate, analyze and solve certain problems in revealing a truth. This legal research uses a normative juridical legal approach method. A deductive study begins with an analysis of the articles in the legislation that govern the above problems. Jurisdictional legal research means research that refers to existing literature studies or to secondary data. Meanwhile, normative means that legal research aims to obtain normative knowledge about the relationship between one regulation and other regulations and its implementation in practice. It initially examined secondary data which was then followed by research on primary data in the field or its practice.

This approach is actually about finding the law in action of a regulation so that real behavior can be observed as a result of the enactment of positive law. In addition, it is evidence of whether or not it has run accordingly with normative legal provisions (codification or Law). ${ }^{7}$ The juridical aspect in this study is the legislation or norms that contain provisions regarding matters relating to legal protection against holders of Mining Business License Area (WIUA). Meanwhile, the empirical aspect is the practice of providing legal protection to holders of Mining Business License Area based on applicable laws and regulations. It is done through research to collect objective data as primary data.

The research specifications used in this study are descriptive analytical. Descriptive means that this study describes the condition of the object of research in detail, thoroughly, and systematically about everything or a number of factors that influence data acquisition. Then, it is collected, compiled, explained and then analyzed. Analytical means grouping, linking, and comparing provisions regarding legal protection against holders of Mining Business License Area.

Every legal research requires primary data and secondary data. ${ }^{8}$ Primary data is data obtained directly from samples and respondents through interviews and questionnaires while library research is only supporting data. ${ }^{9}$ Secondary data is data that the researcher does not collect by him/ herself; for instance, statistics bureau, magazine, information or other publications. Secondary data is supporting/ complementary data obtained through library research. Library research aims to examine, study, and trace secondary data including primary materials, namely binding legal materials. Secondary materials provide an explanation of primary and tertiary legal materials. In this case, tertiary legal materials provide guidance and explanation of primary and secondary legal materials. ${ }^{10}$

The data analysis technique applies qualitative analysis or an analysis that does not base its research on collecting data from a large location with many respondents or multiple answers but with information based on global (general) reality. So, even though the location is limited and the respondents are few, if the data acquisition is a valid reality, the data is enough to prove the truth. ${ }^{11}$ Obtaining data from field research is prepared in a complete, systematic, correct, and consistent manner. The data is then analyzed based on the existing circumstances, facts, and theories that are associated with the research problems. It also studies what the respondent stated verbally or in writing.

\section{Results and Discussion}

\section{Share and Obligation of Shareholder in Limited Liability Company}

The company's shares are issued in the name of the owner based on the terms of share ownership stipulated in the articles of association by observing the requirements stipulated by the competent agency

\footnotetext{
${ }^{7}$ Abdulkadir Muhammad, Law and Legal Research, PT Citra Aditya, Bandung, 2004, page 132

${ }^{8}$ Guidelines for Writing Research Proposal and Thesis, Graduate Program in Notary at Andalas University, Padang, 2012 , page 7.

${ }^{9}$ Ronny Hanitijo Soemitro, Legal Research Method and Jurimetry, Ghalamania Indonesia, Jakarta, 1990, page 10

${ }^{10}$ Soerjono Soekanto, Introduction to Legal Research, UI-Pres, Jakarta, 1982, page 52

${ }^{11}$ Hilman Hadikusuma, Method of Making Paper or Legal Thesis, Mandar Maju, Bandung, 1995, page 99.
} 
in accordance with the provisions in the legislation. If the requirements for share ownership do not meet the requirements, the party that obtains share ownership cannot exercise the rights as shareholders and the shares are not taken into account in the quorum which must be achieved in accordance with the provisions of this Law and/or articles of association.

If these conditions are not met, the shareholders will not be able to enjoy their rights as stipulated in Article 52 of the Limited Liability Company Law stating that the shares give the owner the right to: (a) attend and issue votes at the General Meeting of Shareholders, (b) receive payment of dividends and the remaining assets resulting from liquidation, and (c) exercise other rights under this Law.

\section{Mining License and its Relationship with Shareholders}

The first thing that needs to be explored here is the granting of government rights to mining license holder. It returns to the right of the state as the sole ruler of mining natural resources that can provide mining licenses to other parties. It means that mining license holders have also obtained the rights from the government as executors of mining operations. Thus, in addition to containing the identity of the holder, the mining license also contains the rights granted by the state to the holder to cultivate a mine as stated in the mining license.

In other words, mining licenses contain certain rights that can be run by a company. Since the mining license contains certain rights, it is part of the assets of the company. The implication, if a mining license is part of the company's assets, is included in the company's business. Rights are included in objects because objects are goods or rights that can be controlled by property rights or become objects of law. ${ }^{12}$ Therefore, since mining licenses contain rights, it can be said to be an object that can be owned by the company. Therefore, it is included in the company's business.

However, it is necessary to know that mining license also has a public legal aspect because it is in the form of license. This gives the meaning that mining license has one function ${ }^{13}$ like a license. Since the mining license has one function, the government has a higher authority than the mining license holder. If, based on the law, the mining license holder violates the provisions required by the government, administrative sanctions can apply to mining license holder, which of course will be carried out according to the law. One of the sanctions is of course the revocation of mining license. ${ }^{14}$ This confirms that the government position is stronger than the mining license holder.

Then, shares are also part of material and become one of the company's business. Therefore, shares also have material characteristics. The most basic difference between shares and the other types of objects can be seen from the rights that they contain. Shares have certain rights regulated in the Limited Liability Company Law, especially in Article 52, namely voting rights and attendance rights at the General Meeting of Shareholders and dividends from liquidated assets. Based on this, the first right determines how much the transfer and control of a company if there is an acquisition of the target company, including the mining license.

When the acquisition takes place, if the process of buying and selling shares is deemed complete and in accordance with the procedure, the transfer of shares as much as the agreed percentage will occur using a share transfer deed because shares are movable object even though has no the real form. Therefore, transfer and control basically occur in accordance with the rights contained in these shares, namely to control the company at the General Meeting of Shareholders. This mechanism may influence mining license.

\footnotetext{
${ }^{12}$ Rachmadi Usman, Material Law, Sinar Grafika, Jakarta, 2011, page 49.

${ }^{13}$ Philipus M. Hadjon et al, Introduction to Indonesian Administrative Law, 9th print, Gajah Mada University Press, Yogyakarta, 2005, page 47.

${ }^{14}$ Article 51 of the Mineral and Coal Law.
} 
Based on the law, the mining license itself is not transferable because of different legal aspects and arrangements. To transfer a mining license, it must carry out administrative requirements in accordance with the provisions in Article 7A Government Regulation No. 24 of 2012 concerning amendment to Government Regulation No. 23 of 2010 concerning Implementation of Mineral and Coal Mining Business Activities. Transfers from mining license only lie in the control of them in the number of transferred shares. Since the mining license is also individual and legally listed on behalf of who the Mining License is held, the transfer of the mining license holder does not automatically occur because the acquisition of shares does not change the legal entity of the acquired company. In other words, change only occurs in the structure of its shareholders while the legal entity remains running.

However, the company's assets will economically be transferred according to the nominal amount of the shares even though legally there are no changes to any transfers except only the shares in accordance with the share sale and purchase agreement in the acquisition process. Because, in economic view, all company's assets actually have their respective links to profit.

\section{Case Study}

To illustrate the above problems, the author took an example from the case of revocation of mining license by the Regent of Penajam Paser Utara. This revocation was then sued by the mining license holder to the State Administrative Court in Samarinda. This case is registered as a case with No. 16/G/2011/PTUN-SMD, which will be described in the following sections.

\section{The Parties}

a. Plaintiff: PT PASIR PRIMA COAL INDONESIA, a Limited Liability Company established under Indonesian law located in Balikpapan Municipality in accordance with Deed No. 53 dated August 13, 2008 made by Notary Melania Miensye Hambali, SH., having her address at Balikpapan. The deed was ratified by the Decree of the Minister of Law and Human Rights of the Republic of Indonesia No: AHU 71379.AH.01.02 of 2008 concerning Approval of Deed of Amendment to the Articles of Association of the Company and was stipulated on October 8, 2008. In this case it was represented by HENGKI WIJAYA OEY a citizen of Indonesia, having his address at Jalan Jenderal Sudirman No. 279 RT 002, Damai Village, which in this case acts as the President Director. Therefore, he acted for and on behalf of PT PASIR PRIMA COAL INDONESIA, hereinafter abbreviated as PT PPCI.

b. Defendant: REGENT OF PENAJAM PASER UTARA, having his address at Jalan Provinsi No. 2, Penajam Paser Utara, East Borneo.

\section{Disputed Object}

The object of the dispute in this case was the Decree of the Regent of Penajam Paser Utara No. 460/63/Dis tamben/II/2011 dated February 7, 2011 concerning Revocation of the Decree of the Regent of Penajam Paser Utara Number: 545/03-Eksploitasi/Ekonomi/VI/2008 concerning Exploitation Coal Mining License for PT PPCI.

\section{Reason for Lawsuit}

a. The plaintiff was the holder of the Coal Exploitation Mining Authority based on the Decree of the Regent of Penajam Paser Utara No. 545-03-eksploitasi/Ekonomi/VI/2008 concerning PT PPCI's Exploitation Coal Mining Power of Attorney in Mentawir Village, Sepaku District, Paser Utara Regency covering an area of 3,964.9 Ha which was valid from June 23, 2008 to June 23, 2018. 
b. The plaintiff also had a Mining Authority for Transportation and Sales No. 540/03/KPAJ/Ekonomi/VII/2008 dated July 3, 2008. The plaintiff also had a Loan to Use Production Forest Area based on the Decree of the Minister of Forestry No. SK.374/Menhut-II/2008 dated October 21, 2008.

c. Based on the Circular of the Director General of Mineral, Coal and Geothermal No. 03.E/31/DJB/2019dated 30 January 2009, Mining Authorities that are still valid must be adjusted to the mining license. For this purpose, the plaintiff submitted 4 letters to the defendant or the Regent Penajam Paser Utara, which consisted of:

i. Letter Number: 006/PPCI-BPP/XI/2009 dated November 5, 2009 concerning Application for Amendment of Mining Authority to become a mining license.

ii. Letter Number: 008/PPCI-BPP/III/2010 dated March 30, 2010 concerning Application for Amendment of Mining Authority to become a mining license.

iii. Letter Number: 010/PPCI-BPP/IV/2010 dated 29 April 2010 concerning Application for Adjustment/ Renewal of Mining Authorization License into mining license for production operation.

iv. Letter Number: 012/PPCI-BPP/V/2010 dated May 18, 2010 concerning Application for Adjustment of Mining Authorization License into mining license for production operation.

d. The plaintiff's letters had not yet been followed up by the defendant.

e. The plaintiff filed a lawsuit because he was harmed by the action of the Defendant/ Regent of Penajam Paser Utara who issued Letter No. 460/63/Distamben/II/2011 dated 7 February 2011 concerning Revocation of the Decree of the Regent of Penajam Paser Utara Number: 545/03Eksploitasi/Ekonomi/VI/2008 concerning PT PPCI's Exploited Coal Mining License. Then, the defendant issued a mining license for PT South Pacific Resources and PT Mandiri Sejahtera Energyndo in the area where the plaintiff had had a Mining Authority over it; i.e. Mining Authority of Transportation and Sales No. 545/03/KP-AJ/Ekonomi/VII/2008 dated July 3, 2008.

f. The plaintiff was never given the opportunity to defend his interests as stipulated in Article 41 paragraph 1 and 2 Government Regulation No. 75 of 2001 concerning the Second Amendment to Government Regulation No. 32 of 1969 concerning the Implementation of Law No. 11 of 1967 concerning the Basic Provisions of Mining Jo. Law No. 4 of 2009 concerning Mineral and Coal Mining.

\section{Defendant's Answers}

a. Hengki Wijaya Oey had no legal standing since in the Exploitation Coal Mining No. 545/03Eksploitasi/Ekonomi/VI/2008, the Hengki Wijaya Oey's name was not listed as a board of directors or commissioners of PT PPCI. Therefore, he was not entitled to file a lawsuit in the State Administrative Court.

b. In the company's internal, changes to the PT PPCI's articles of association which had included Hengki Wijaya Oey as President Director are actually legitimate. However, if it was associated with the Decree of the Regent of Penajam Paser Utara No. 545/03-Eksploitasi/Ekonomi/VI/2008, it violated the law because it violated (a) Tenth Dictum of Decree of the Regent of Penajam Paser Utara No. 545/03-Eksploitasi/Ekonomi/VI/2008 which prohibits the transfer of Mining Authority to other parties without the approval of Regent of Penajam Paser Utara and also violates of (b) Fourth Dictum of the Minister of Forestry Decree No. SK.374/Menhut-II/2008 which prohibits the transfer of this license to any party without the approval of the Minister of Forestry. 
c. Based on the Third Dictum of the Decree of the Regent of Penajam Paser Utara No. 545/03Eksploitasi/Ekonomi/VI/2008, the plaintiff had the right to revoke licenses even though the validity period had not expired especially if administrative requirements were not met; for example, making periodic reports. This was based on the provisions of Article 119 letter (a) of Law No. 4 of 2009 stating that: "The mining license or special mining license is revoked by the Minister, Governor, Regent/ Mayor in accordance with their authority if the mining license or special mining license holder did not fulfill the obligations stipulated in the mining license or special mining license and statutory regulations-invitation".

d. The plaintiff justified the reason for revoking PT PPCI's license because PT PPCI had not deposited Non-Tax State Revenues for the Use of Forest Areas.

e. The plaintiff's reason for not processing PT PPCI's request to change the Mining Authority into a mining license was because one of the requirements was not fulfilled. In this case, the owner of the license was "Tjioe Junaedi or Nonny Oentoro" while the one who submitted the application was "Hengki Wijaya Oey".

\section{Legal Considerations}

a. Based on the evidence submitted by the plaintiff, in the form of a report on the General Meeting of Shareholders of the Limited Liability Company PT PPCI No. 108 dated 21 February 2005 made before Melania Miensye Hambali a Notary in Balikpapan, a fact was revealed that Hengki Wijaya Oey had bought 200 shares or valued at IDR 200,000,000 (two hundred million rupiah) and then Hengki Wijaya Oey was appointed as Managing Director PT PPCI. On that basis, the Panel of Judges rejected the reason of the defendant who considered that Hengki Wijaya Oey did not have the legal standing to sue.

b. The Panel of Judges views that the report of the General Meeting of Shareholders of the Limited Liability Company PT PPCI No. 108 dated February 21, 2005 made before Melania Miensye Hambali a Notary in Balikpapan refers to a legal event in the form of sale and purchase of shares or known as transfer of rights to shares carried out by a transfer of rights as referred to in Article 56 paragraph (1) of the Law No. 40 of 2007 concerning Limited Liability Companies. Thus, this is not the same as the event of the transfer of rights to shares or the transfer of share ownership in the capital market as stipulated in Article 56 Paragraph (5) of Law No. 40 of 2007 concerning Limited Liability Companies. Thus, the Panel of Judges considered that the legal event in the form of the sale and purchase of shares in PT PPCI was not a legal event to transfer or sell to buy an Exploitation Mining Authority to another party.

c. The Panel of Judges considered that what happened to PT PPCI was the transfer of share ownership based on Article 56 Paragraph (1). Therefore, it is not subject to the provisions of Article 93 Paragraph (3) which requires the transfer of ownership of the shares to notify the Minister, Governor, or Regent/ Mayor.

d. The Panel of Judges considered that the validity of the clear and complete information about the city where Hengki Wijaya Oey lived, who had acted as the Managing Director on behalf of PT PPCI in this case did not result in the claim of the plaintiff becoming void.

e. The Panel of Judges considered that before issuing the object of the dispute, the defendant/ Regent of Penajam Paser Utara had never issued a Warning Letter as stipulated in Article 32 of the Regulation of the Minister of Energy and Mineral Resources No. 28 of 2009 concerning the Implementation of Mineral and Coal Mining Services and Article 13 Government Regulation No. 29 of 2009 concerning Procedures for Determining the Amount of Payments and Depositing of Non-Tax State Revenue that is Due. Therefore, the Panel of Judges argued that the plaintiff could not be imposed with administrative sanctions. 
f. The Panel of Judges found no evidence that before the defendant issued the object of the dispute to the plaintiff, the defendant never requested information or defense from the plaintiff.

g. The Panel of Judges argued that the plaintiff's request in the petitum/ claim to ask the defendant to issue mining licenses for production operations was objectionable because the plaintiffs were proven to have never carried out socialization to the local community.

\section{Decisions}

Based on the legal considerations stated by the Panel of Judges as described above, the Panel of Judges decided to:

a. Refuse the defendant's exception

b. Partially grant the claim of the plaintiff:

c. Declare the decision of the defendant/ Regent of Penajam Paser Utara No. 460/63/Distambem/II/2011 dated February 7, 2011 concerning Revocation of Decree of the Regent of Penajam Paser Utara No. 545/03-Eksploitasi/Ekonomi/VI/2008 concerning License for Coal Mining Authorization Exploitation of PT PPCI is void.

d. Order the defendant to revoke the decision of the defendant/ Regent of Penajam Paser Utara No. 460/63/Distambem/II/2011 dated February 7, 2011 concerning Revocation of Decree of the Regent of Penajam Paser Utara No. 545/03-Eksploitasi/Ekonomi/VI/2008 concerning PT PPCI's Exploitation Coal Mining Power of Attorney.

e. Refuse the claim of the plaintiff other than and the rest.

f. Sentence the plaintiff to pay court fees of IDR 251,000 (two hundred fifty-one thousand rupiah).

\section{Legal Analysis of the Case}

Based on the above case, we can conclude that the report of the General Meeting of Shareholders of the Limited Liability Company PT PPCI No. 108 dated February 21, 2005 made before Melania Miensye Hambali a Notary in Balikpapan refers to a legal event in the form of sale and purchase of shares or known as transfer of rights to shares carried out by a transfer of rights as referred to in Article 56 paragraph (1) of the Law No. 40 of 2007 concerning Limited Liability Companies. Based on the provisions of Article 56, the acquisition or transfer of shares is an internal legal act of a corporate legal entity. This action does not need to get ministerial approval, but this legal action must be reported to the minister and must be included in a special register as required by Article 50 Paragraph (1) of the Limited Liability Company Law.

Thus, this is not the same as the event of the transfer of rights to shares or the transfer of share ownership in the capital market as stipulated in Article 56 Paragraph (5) of Law No. 40 of 2007 concerning Limited Liability Companies. Therefore, we can conclude that the legal event in the form of selling and buying shares in PT PPCI is not a transferring or selling legal event buying an Exploitation Mining Authority to another party, as stipulated in Article 93 Paragraph (3) which requires that the transfer of ownership of shares must notify Minister, Governor, or Regent/ Mayor.

Both of the above were used by the Judges of the Samarinda State Administrative Court to decide and declare that the Decree of the Regent of Penajam Paser Utara No. 460/63/Distambem/II/2011 dated February 7, 2011 concerning Revocation of Decree of the Regent of Penajam Paser Utara No. 545/03Eksploitasi/Ekonomi/VI/2008 concerning Exploitation Coal Mining Authorization License of PT PPCI is void. 
Even though the Panel of Judges of the Samarinda State Administrative Court canceled the Decree of the Regent of Penajam Paser Utara No. 460/63/ Distambem/II/2011 dated February 7, 2011, this decision has not provided legal certainty to PT PPCI because the Samarinda State Administrative Court did not require the Regent of Penajam Paser Utara to issue a mining license for PT PPCI. Thus, the decision of the Samarinda State Administrative Court has also not become the basis for PT PPCI to carry out coal exploitation activities.

Another legal uncertainty arising from this decision is that the Mining License of PT PPCI still coincides with the Mining License area of PT South Pacific Resources and PT Mandiri Sejahtera Energyndo in the area where the plaintiff has been given mining authority; i.e. Mining Authority of Transportation and Sales No. 545/03/KP-AJ/Ekonomi/VII/2008 dated July 3, 2008. The decision of the Samarinda State Administrative Court did not cancel the Mining License so that the Mining License of PT South Pacific Resources and PT Mandiri Sejahtera Energyndo remained in force.

\section{Liabilities of the Acquirer to the Mining License of the Acquired Party}

The acquirer actually does not have any legal responsibility for the acquired party, except that it can indeed be proven by the acquirer to commit bad faith in the acquisition process and after the acquisition that can harm other parties including third parties. So, they will be liable directly through the court or other means.

Meanwhile, the legal responsibility of the acquired party is that it must conduct an administrative process to the relevant agencies, namely the Ministry of Energy and Mineral Resources to fulfill the provisions as referred to in Article 93 of the Mineral and Coal Law.

The party that acquires the company that owns the Mining License has the same obligations as the acquired party. The acquirer must comply with the provisions in the form of mandatory obligations to the Mining License holder, such as the provisions of Article 95 to 112 of the Mineral and Coal Law.

The obligation that must be borne is the obligation to carry out mining and good financial management and preserve the environment, as stipulated in Article 95 up to Article 98 of the Mineral and Coal Law. The Obligations of the Mining License Holder and the Special Mining License are as follows:

a. apply the principles of good mining techniques;

b. manage the finance in accordance with the Indonesian accounting system;

c. increase the added value of mineral and/or coal resources;

d. carry out development and empowerment of local communities; and

e. comply with tolerance limits for environmental support capacity.

f. carry out mining work safety and health provisions and mining operations safety;

g. manage and monitor the mining environment, including reclamation and post-mining activities;

h. make efforts to conserve mineral and coal resources;

i. manage the remaining mining material from a mining business activity in the form of solid, liquid or gas to meet environmental quality standards before being released into the environmental media.

j. guarantee the application of standards and environmental quality standards in accordance with the characteristics of an area. 
k. preserve the function and support capacity of the water resources concerned in accordance with the provisions of the legislation.

In addition to the obligations of letters a to $\mathrm{k}$ above, the acquirer company as the holder of the Mining License and the Special Mining License also bear post-mining obligations; i.e. the obligation to conduct mine reclamation. This is regulated in Article 99 and Article 100 of the Mineral and Coal Law. The obligations in question are as follows:

a. submit a reclamation plan and post-mining plan when applying for a Production License Mining Operation or a Special Mining License Production Operation.

b. carry out reclamation and post-mining activities carried out in accordance with the designation of post-mining land.

c. provide reclamation guarantee funds and post-mining guarantee funds.

Increasing the added value of mineral resources and respect for local communities is also the obligation of the company to acquire the Mining License holder. This is regulated in Article 102 up to Article 111 of the Mineral and Coal Law. These obligations are as follows:

a. increasing the added value of mineral and/or coal resources in the implementation of mining, processing and refining, as well as the utilization of minerals and coal.

b. processing and refining domestic mining products and processing and refining mining products from other Mining License holders and Special Mining License.

c. Having cooperation to conduct purification with business entities, cooperatives, or individuals who have obtained a Mining License or Special Mining License.

d. paying production fees if the coal produced is to be sold.

e. prioritizing the use of local labor, goods and services in the country in accordance with the provisions of the legislation.

f. involving local entrepreneurs in the area in accordance with the provisions of the legislation.

g. developing community development and empowerment programs that must be consulted with the Government, regional government, and the community.

h. submitting all data obtained from the results of exploration and production operations to the Minister, Governor, or Regent/ Mayor in accordance with his authority.

i. providing periodic written reports on work plans and implementation of mineral and coal mining activities to the Minister, Governor, or Regent/ Mayor in accordance with their authority.

In addition to the above obligations, the acquirer company has the same obligations as the acquired party. For example, an acquired party can be sued legally if in the process and after the acquisition does have a legal flaw or its actions can harm the interests of another party or a third party. In addition to be sued in a civil manner, the Mining License company can also be subjected to administrative sanctions if it is proven to violate the provisions referred to in Article 93 paragraph (2) and paragraph (3), i.e. by not notifying authorized officials and by making acquisitions that are contrary to the provisions of the laws and regulations. The sanctions are contained in Article 151 paragraph (2) of the Mineral and 
Coal Law in the form of a written warning, temporary suspension of part or all of the exploration or production operations and/or revocation of the Mining License, People Mining License or Special Mining License.

\section{Conclusion}

1. Taking over of PT PPCI's shares, based on the report of the General Meeting of Shareholders of Limited Liability Company No. 108 dated February 21, 2005 made before Melania Miensye Hambali a Notary in Balikpapan, is a legal event in the form of sale and purchase of shares or known as the transfer of rights to shares made by a transfer of rights as referred to in Article 56 paragraph (1) of the Law No. 40 of 2007 concerning Limited Liability Companies. Based on the provisions of Article 56 above, the acquisition or transfer of shares is an internal legal act of a corporate legal entity. This action does not need to get ministerial approval but must be reported to the minister and included in the special register as required by Article 50 Paragraph (1) of the Limited Liability Company Law. Thus, this legal event is not the same as the transfer of rights to shares or the transfer of share ownership in the capital market as stipulated in Article 56 Paragraph (5) of Law No. 40 of 2007 concerning Limited Liability Companies. Thus, we can conclude that the legal event in the form of selling and buying shares in PT PPCI is not a legal event of transferring or selling Exploitation Mining Authority to other parties, as stipulated in Article 93 Paragraph (3) which requires that the transfer of ownership of shares must notify the Minister, Governor, or Regent/ Mayor.

2. The acquirer actually does not have any legal responsibility to the acquirer unless it can be proven that the acquirer made bad faith during and after the acquisition process that could harm other parties including third parties. So, it can be directly liable through the court or other means. Meanwhile, the legal liability of the acquired party is that it must conduct an administrative process to the relevant agencies, namely the Ministry of Energy and Mineral Resources to fulfill the provisions as referred to in Article 93 of the Mineral and Coal Law. The party that acquires the company that owns the Mining License has the same obligations as the acquired party. The acquirer must comply with the provisions in the form of required obligations to the holder of the Mining License, such as the provisions of Article 95 to 112 of the Mineral and Coal Law.

\section{References}

Books

Bahder Johan Nasution, Legal Research Methods, Bandung, Mandar Maju, 2008, page 86.

Habib Adjie, Nullification and Cancellation of Notarial Deed, Refika Aditama, Bandung, 2011, page 66.

McConville, Mike, ed. Research methods for law. Edinburgh University Press, 2017.

Unwin, P. T. H., and Tim Unwin, eds. ICT4D: Information and communication technology for development. Cambridge University Press, 2009.

Journal

Djanggih, Hardianto. "The Phenomenon Of Cyber Crimes Which Impact Children As Victims In Indonesia." Yuridika 33.2 (2018): 212-231. 
Mohammad Zamroni, 2009, Technological Development and Its Impact on Life, Da'wah Journal Vol. X No. 2. Yogyakarta

Schotel, Bas. "Legislation, Empirical Research and Juridical Law." The Theory and Practice of Legislation 1.3 (2013): 501-532.

Legislation

Law No. 30 of 2004 concerning Notary Position

Law No. 2 of 2014 concerning Amendment to Law No. 30 of 2004 concerning Notary Position

Law No. 11 of 2008 concerning Information and Electronic Transactions.

Law No. 40 of 2007 concerning Limited Liability Companies

\section{Copyrights}

Copyright for this article is retained by the author(s), with first publication rights granted to the journal. This is an open-access article distributed under the terms and conditions of the Creative Commons Attribution license (http://creativecommons.org/licenses/by/4.0/). 